\title{
Potensi Spirulina platensis sebagai sumber kosmetik dan bioplastik (review)
}

\section{Potency of Spirulina platensis as a source of cosmetic and bioplastic (review)}

\author{
Muhamad Maulana Azimatun Nur ${ }^{a *}$, Tutik Muji Setyoningrum ${ }^{\mathrm{a}}$, Halim Nur Aziz Suwardi ${ }^{\mathrm{b}}$, Bety Alfitamara ${ }^{\mathrm{b}}$, Adi \\ Kurniawan ${ }^{\mathrm{a}}$, Vinka Azzah Prananda ${ }^{\mathrm{a}}$, Dwi Nur Afni ${ }^{\mathrm{a}}$, Sheila Alodia ${ }^{\mathrm{a}}$, Retno Pamularsih ${ }^{\mathrm{a}}$ \\ aJurusan Teknik Kimia, Fakultas Teknik Industri,Universitas Pembangunan Nasional “Veteran” Yogyakarta, Sleman, \\ Yogyakarta, Indonesia \\ ${ }^{b}$ Divisi Produksi, PT Spiralife Bioteknologi Indonesia, Gedung Graha Pena, Jl. Ahmad Yani No.88, Ketintang, Gayungan, \\ Surabaya City, East Java 60231
}

\section{Artikel histori : \\ Diterima: 23 Oktober 2021 \\ Diterima dalam revisi: 30 Oktober 2021 \\ Diterima: 30 Oktober 2021 \\ Online: 01 November 2021}

\begin{abstract}
ABSTRAK: Spirulina plantesis merupakan salah satu Jenis mikroalga yang mempunyai banyak kegunaan, beberapa di antaranya yaitu untuk pembuatan kosmetik. Di samping itu, Spirulina platensis merupakan cyanobacteria yang dapat mengakumulasi bioplastik jenis polihidroksibutirat (PHB). Review paper ini membahas tentang potensi produksi Spirulina platensis sebagai sumber bioplastik dan kosmetik. Dari pemaparan, Spirulina memiliki senyawa yang memiliki kandungan bioaktif C-phycocyanin yang dapat menghambat kerusakan sel dan sangat potensial diaplikasikan untuk kosmetik. Kandungan PHB yang ada di Spirulina cenderung kecil. Untuk menurunkan biaya produksi PHB, dapat dilakukan konsep biorefinery, dengan mengambil komponen bioaktif, sementara residunya dapat digunakan sebagai sumber PHB.
\end{abstract}

Kata Kunci: Spirulina platensis; polihidroksibutirat; kosmetik; C-phycocyanin; anti-aging

\begin{abstract}
Spirulina plantesis is a cyanobacteria that has many purposes such as for cosmetics, and food industry. In addition, Spirulina platensis can accumulate polyhydroxybutyrate (PHB), a type of bioplastic. This review discussed the potency of Spirulina platensis as a source of bioplastics and cosmetics. From the review, Spirulina contained bioactive compound, C-phycocyanin, which can inhibit cell damage and is very potential to be applied for cosmetics. The PHB content in Spirulina tends to be small compared to other microalgae. To reduce the cost of PHB from Spirulina, the biorefinery concept can be applied, by recovery the bioactive components (C-phycocyanin), while the residue can be used as a source of PHB.
\end{abstract}

Keywords: Spirulina platensis; polyhydroxybutyrate; cosmetics; C-phycocyanin; anti-aging

\section{Pendahuluan}

Selama beberapa dekade terakhir, para peneliti produk alam telah mengalihkan perhatian mereka ke sumber daya alam berbasis laut seperti sumber tanaman, hewan, dan mikroorganisme. Salah satu contoh sumber alam tersebut adalah mikroalga yang dapat digunakan untuk berbagai macam produk primer dan sekunder, serta produk metabolit dengan produk turunan yang banyak dan bervariasi, misalnya, produk farmasi yang bekerja melawan kanker dan peradangan, atau sebagai anti-virus dan imunomodulasi (Kiuru et al., 2014).
Penggunaan mikroalga untuk tujuan nutrisi sudah ada sejak ribuan tahun yang lalu; dari Cina, di mana Nostoc digunakan untuk bertahan dari kelaparan, lalu di daerah Chad dan Meksiko di mana spesies mikroalga dan cyanobacteria (Arthrospira, Spirulina) telah digunakan oleh manusia selama ribuan tahun (Singh dkk., 2015; Spolaore dkk., 2006; Milledge dkk., 2011). Meskipun penggunaannya teradisional, kultur mikroalga masih merupakan bioteknologi modern (Milledge, dkk., 2011).

Berbagai artikel telah mengulas bahan aktif utama yang berasal dari cyanobacteria dan mikroalga. Cyanobacteria (sebelumnya dikenal sebagai ganggang biru-

*Corresponding Author:

Email: lanaazim@upnyk.ac.id 
hijau) ditemukan di berbagai habitat karena sebagian besar dapat tumbuh di air tawar dan air asin, serta beberapa diantaranya di lingkungan laut. Meskipun organisme prokariotik, cyanobateria juga mampu melakukan fotosintesis (Tamagnini dkk., 2002), dan dianggap sebagai salah satu sel fotosintesis paling awal di planet ini. Cyanobacteria yang paling banyak dipelajari adalah Spirulina (Arthrospira), dan Aphanizomenon, dengan komponen yang paling umum digunakan adalah karotenoid, klorofil, phycocyanin, asam amino, mineral, di antara banyak lainnya (Singh dkk., 2005).

Saat ini, produksi global mikroalga dan cyanobacteria sebagian besar digunakan untuk produk komersial bernilai tinggi mengingat biomassa alga mengandung pigmen, protein, asam lemak esensial, polisakarida, vitamin, dan mineral yang sangat menarik sebagai produk alami, baik sebagai kosmetik, pangan, dan farmasi. Makalah ini bertujuan untuk mereview potensi Spirulina platensis sebagai sumber kosmetik.

\section{Spirulina platensis}

Mikroalga adalah mikroorganisme fotosintesis prokariotik dan eukariotik. Ada dua kelompok prokariota (Cyanophyta dan Prochlorophyta) dan divisi yang berbeda dari eukariota (Chlorophyta, Rhodophyta, Phaeophyta, Bacillariophyta, dan Chrysophyta) (Mutanda, 2013).

Spirulina adalah mikroalga berfilamen mengambang bebas dengan karateristik filamen spiral. Pada umumnya disebut Arthrospira, termasuk dalam kelas cynobacteria dengan kemampuan fotosintesis yang khas (Sapp, 2005 dan Komarek dkk, 2009).

Spirulina menonjol karena kandungan proteinnya yang tinggi dan adanya asam lemak esensial, vitamin, dan mineral. Keanekaragaman dan keserbagunaan dari Spirulina mempromosikan penerapannya dalam berbagai produk industri, dari biofuel, hingga suplemen makanan dan kosmetik bernilai tinggi (Slocombe, 2016 dan Gershwin, 2007).

\section{Manfaat dan kandungan Spirulina}

Spirulina saat ini telah menjadi tren, salah satunya sebagai perawatan kulit karena kandungannya yang kaya akan manfaat. Produk Spirulina yang sering dijumpai di pasar adalah sebagai anti-aging, termasuk pelembab, antioksidan dan sifat mencerahkan, kedua sebagai anti jerawat, dan penyembuhan luka (Ragusa dkk, 2021). Selain itu, Spirulina juga dapat menjadi anti inflamasi, anti kanker, anti bakteri, imunomodulator, serta sebagai pelindung dari sinar matahari. Banyak penelitian ilmiah juga menunjukkan bahwa Spirulina kaya akan kandungan protein (50-70\%), asam lemak essensial, dan nutrisi lain seperti mineral, vitamin, dan lain-lain (Furmaniak dkk, 2017). Terlebih lagi, Spirulina memiliki berbagai senyawa fitokimia seperti asam fenolik, tokoferol dan B-karoten, yang semuanya diketahui menunjukkan sifat antioksidan yang kuat (Sahin, 2018).

Spirulina dapat dijadikan pelembab karena Spirulina dapat memperbaiki struktur epidermis dan bertindak sebagai penghidrasi kulit pada lapisan terluar kulit, terutama untuk perlindungan kulit, anti penuaan dan untuk mengontrol minyak berlebih di dalam jaringan kulit (Delsin dkk, 2015).

Aspek penting yang dapat menyebabkan penuaan kulit adalah kurangnya peptida dalam matriks ekstraseluler dermis. Peptida adalah rantai pendek residu asam amino yang terlibat dalam beberapa proses fisiologis, seperti inflamasi atau peradangan, respon imun dan remodeling kulit, serta menstimulasi sintesis dari struktural protein (kolagen dan elastin). Oleh karena itu, produk kosmetik yang kaya akan peptida dapat mencegah timbulnya kerutan dan tanda-tanda penuaan (Michalek dkk., 2019). Spirulina, terutama Spirulina yang telah difermentasi, mengandung senyawa peptida yang sangat bermanfaat sebagai sumber anti penuaan (Castro dkk., 2019).

Spirulina yang dikenal akan tingginya antioksidan ini juga dapat mengurangi hiperpigmentasi kulit, melindungi kulit dari kerusakan akibat sinar matahari (misalnya, photoaging) dengan menghambat kerusakan dermis. Selain itu, dalam menangani hiperpigmentasi kulit yang tujuan akhirnya adalah mencerahkan kulit, strategi yang paling dapat diandalkan untuk mengatasi masalah ini adalah menggunakan inhibitor tirosinase. Arbutin, asam kojic dan hidrokuinon adalah inhibitor tirosinase yang paling terkenal. Tetapi penggunaannya saat ini terbatas karena efek tertentu seperti iritasi dan alergi (Sahin, 2018). Oleh karena itu, Spirulina dapat menjadi alternatif inhibitor tirosinase yang lebih aman. Gabungan dari sifat antioksidan dan antiinflamasi dari Spirulina dapat memberikan efek anti tumor terhadap iradiasi UVB di kulit sehingga hal ini menjadi peran penting dalam pencegahan kanker kulit (Costa dkk, 2017). Spirulina juga efektif dalam penyembuhan luka karena kandungan flavonoid dan triterpenoidnya bertindak sebagai zat dan agen antimikroba (Panigrahi dkk, 2011)

\section{Spirulina sebagai campuran kosmetik}

Kulit adalah bagian terluar tubuh yang melindungi tubuh dari benturan, gesekan, dan aktivitas fisik lainnya. Secara struktural, kulit dibagi menjadi tiga lapisan yakni, epidermis, dermis, dan hipodermis. Bagian epidermis melindungi kulit dari sinar UV dan menentukan warna kulit (Lai-Cheong dan McGrath, 2013; McGrath dkk, 2004). Pada bagian dermis terjadi proses regenerasi sel dan menjaga kelembaban kulit. 
Lapisan hipodermis adalah tempat penyimpanan energi dalam bentuk lemak dan sebagai insulator kulit (Kim dkk, 2019 dan Korosec dkk, 2019).

Melihat fungsi kulit yang sangat penting, bagian tubuh ini juga perlu dijaga dan dirawat agar tetap dapat menjalankan fungsinya dengan baik. Perawatan kulit atau yang dikenal dengan istilah skincare semakin diperlukan karena adanya polusi udara yang semakin meningkat serta perubahan iklim yang dapat mempengaruhi kesehatan kulit. (Aslam dkk., 2021).

Kandungan senyawa bioaktif yang tinggi pada Spirulina menjadikannya banyak diminati oleh para peneliti untuk dijadikan bahan dasar dalam pembuatan kosmetik. Hasil penelitian menunjukan bahwa 45 wanita yang berumur 40-60 tahun diberi asupan Spirulina sebanyak 2,8 gram per hari mengalami peningkatan kualitas kulit, rambut, dan kuku setelah 90 hari observasi. Adanya kandungan Cphycocyanin (C-PC) dan $\beta$-carotene pada Spirulina menjadikannya sebagai sumber antioxidant, antiinflamatory, immunomodulatory, dan photoprotective yang baik. Hasil penelitian menunjukan bahwa kombinasi antara antioxidant dan anti-inflamatory pada Spirulina dapat menangkal radiasi UVB pada kulit (Costa dkk., 2017).

\section{Penuaan dini}

Kulit manusia terdiri dari dua lapisan yaitu epidermis dan dermis, dimana masing-masing mempunyai struktur dan fungsi masing-masing. Epidermis adalah bagian yang paling terbuka dari kulit dan bersentuhan dengan lingkungan luar (Naylor dkk., 2011). Fungsi utama epidermis adalah untuk melindungi kulit dari ancaman lingkungan yang berpotensi berbahaya. Kemudian, di bawah epidermis adalah jaringan dermis, yang merupakan lapisan jaringan ikat, dimana menyediakan ruang mekanik, kompak, dan fleksibel yang menompang fungsi kulit (Baroni dkk., 2012).

Seiring bertambahnya usia, jaringan mengalami perubahan. Perubahan ini berupa penuaan yang mudah dikenali pada kulit manusia (Friedman, 2005). Proses penuaan kulit terjadi melalui dua mekanisme biologis yang berbeda, yakni penuaan kronologis dan photoaging (Farage, dkk., 2008). Penuaan kronologis adalah fenomena yang tidak dapat diubah, dimana mencakup beberapa faktor seperti genetika dan hormonal serta proses metabolisme. Proses perbaikan memainkan peran penting dalam pencegahan penuaan. Ketika sel-sel kulit yang rusak tidak diperbaiki, kemudian terjadi mutasi, ini mengakibatkan penuaan dini (Quan dkk., 2015).

Tidak seperti penuaan kronologis, photoaging adalah hal yang dapat dihindari (Kligman dan Kligman, 1986). Photoaging disebabkan oleh paparan lingkungan, terutama apabila tidak adanya perlindungan jangka panjang yang tidak memadai dari radiasi ultraviolet radiation (UVR) atau sinar UV dari sumber penyamakan buatan (Zouboulis dkk., 2011). Efek pada kulit yang disebabkan oleh UVR bersifat kumulatif dan bergantung pada durasi, frekuensi, dan intensitas paparan. Photoaging bertanggung jawab atas 80-90\% dari penuaan kulit dan merupakan kerusakan yang berasal dari sinar matahari (Natarajan dkk.,2014).

UVR menginduksi matrix metalloproteinases (MMPs), yang bertanggung jawab untuk mendegradasi kolagen di extracellular matriks (ECM). Pada tingkat molekuler, UVR menyerang sel keratinosit dan fibroblas, yang dapat mengaktivasi permukaan sel reseptor untuk memulai kaskade transduksi sinyal. Hal ini menyebabkan berbagai perubahan molekuler dan menyebabkan kerusakan kolagen dan penurunan sintesis kolagen (Loffek dkk., 2011). Diasumsikan bahwa kerusakan kolagen pada kulit diikuti oleh regenerasi yang tidak sempurna dan menghasilkan defisit integritas kulit struktural, pembentukan bekas luka matahari, dan akhirnya, terjadi atrofi kulit yang menyebabkan timbul kerutan pada lapisan kulit dari luar sampai dalam (Pandel dkk., 2013).

Gejala klinis lain yang disebabkan oleh photoaging termasuk pigmentasi atipikal, hilangnya elastisitas, penampilan kasar, kelemahan, kekeringan, kehilangan warna kulit, dan penampilan yang bertekstur kasar. (Helfrich, dkk., 2008 dan Naylor dkk., 2011) Area kulit yang terpapar sinar matahari, termasuk lengan bawah, tangan, leher, dada bagian atas, dan wajah adalah tempatnya dimana penuaan paling sering terjadi (Helfrich, dkk., 2008).

Menurut Friedberg dkk. (2016) dan Osakabe dkk. (2015), proses lain dari kerusakan kulit akibat sinar UV adalah terjadinya fotokarsinogenesis, dimana UVR menginduksi berbagai kerusakan DNA manusia, termasuk dimer siklobutana-pirimidin (CPD) dan 6-4 fotoproduk (64PP). Kerusakan lainnya yang terjadi adalah seperti terjadinya ikatan silang DNA-protein, pemutusan untai DNA, 8-okso-7,8-dihidroguanin (8-okso-dG), oksi- basa pirimidin, timin glikol, kerusakan purin, dan juga dapat merusak kerusakan sitosin (Patrikc dkk. 1976, Peak dkk., 1987, dan Cadet dkk., 2009). Kerusakan ini terjadi sebagian besar karena adanya radikal bebas, terutama oleh reactive oxygen species (ROS). ROS diproduksi karena adanya stres oksidatif intraseluler dan ekstraseluler, yang dianggap sebagai penyebab utama penuaan (Kohl dkk., 2011). Pada kulit, dari 1,5-5\% oksigen yang dikonsumsi diubah menjadi ROS (Poljsak dkk., 2012). ROS secara konstan dihasilkan dalam keratinosit dan fibroblas. (Kammeyer dan Luiten, 2015). 


\section{Spirulina sebagai anti aging}

Menurut Humbret dkk. (2011), dalam memelihara kesehatan kulit, diperlukan nutrisi yang memadai. Kesehatan kulit dapat diamati dari adanya kelainan kulit sebagai respons terhadap adanya kekurangan nutrisi. Suplementasi antioksidan menjadi salah satu strategi untuk memperbaiki kondisi kulit (Basavaraj dkk. 2010). Berdasarkan penelitian yang dilakukan oleh Darvin dkk. (2015) dan Costa dkk. (2017), diketahui Spirulina memiliki komponen bioaktif yang diakui sebagai bahan baku potensial untuk membuat suplemen untuk perawatan kulit.

Costa dkk. (2017) melakukan uji coba terkontrol secara acak, dimana 45 orang wanita berusia 40-60 tahun mengkonsumsi 2,8g/hari Spirulina. Didapatkan hasil berupa sebuah perbaikan yang signifikan pada kulit, rambut dan kuku setelah 90 hari pengamatan. Senyawa bioaktif dari Spirulina, seperti c-phycocyanin (C-PC) dan b-karoten, menunjukkan aktivitas antioksidan yang baik, antiinflamasi, imunomodulator, dan sifat fotoprotektif.

Shanab dkk. (2013), Romay dkk. (2003), dan Liu dkk. (2011), telah membuktikan secara in vitro bahwa Cphycocyanin (C-PC) dapat menangkis peroksil, hidroksil, dan radikal alkoxyl, serta menghambat peroksidasi lipid. Cherng dkk. (2007) juga membuktikan bahwa C-PC dapat menurunkan oksida nitrat (NO) dan menekan inducible nitric oxide synthase (iNOS). Penelitian lain juga melaporkan bahwa C-PC bermanfaat sebagai penghambat ekspresi gen penyebab kanker kulit. Dengan demikian, CPC, senyawa dengan aktivitas anti-inflamasi yang kuat, dapat bertindak sebagai agen kemopreventif namun harus disertai dengan penanganan yang kompleks dan bertingkat (Gupta dkk., 2012).

Yogianti dkk. (2014), menyimpulkan bahwa gabungan sifat antioksidan dan antiinflamasi dari Spirulina memberikan efek antitumor terhadap iradiasi UVB di kulit dan dengan cara ini memainkan peran penting dalam pencegahan kanker kulit. Data ini mendukung peran kemopreventif Spirulina dengan potensi yang menjanjikan untuk digunakan secara luas dalam pengobatan kemoadjuvant kanker kulit. Selain itu, menurut Schafer dkk. (2002), $\beta$-karoten memberikan perlindungan terhadap peroksidasi lipid yang dimediasi oksigen tunggal dan telah dianggap sebagai antioksidan membran in vitro yang efisien.

\section{Kandungan aktif pigmen C-phycocyanin sebagai Antitirosinase}

Pada kulit manusia, pigmen melanin merupakan salah satu konstituen utama warna. Melanin disintesis melalui proses yang melibatkan beberapa reaksi kimia dan enzimatik yang disebut melanogenesis (Bonavernture dkk., 2013).
Tirosinase merupakan salah satu langkah enzimatik yang ditujukan untuk membatasi laju melanogenesis (Sanchez dkk., 1995). Akumulasi melanin dalam jumlah abnormal di beberapa bagian kulit menyebabkan terbentuknya bercak berpigmen yang dapat dianggap sebagai masalah bagi penampilan. Produksi melanin yang berlebihan dan hiperpigmentasi abnormal akibat paparan UVR dapat menyebabkan peningkatan produksi ROS, yang dapat menyebabkan berbagai masalah kulit, seperti bintik-bintik, peradangan, bintik-bintik penuaan dan melasma (Taeib dkk., 2011). Hal ini mendorong penelitian dengan topik untuk mengidentifikasi pemutihan kulit yang efektif dan aman.

Komponen bioaktif dari Spirulina, C-phycocyanin (C-PC), diketahui dapat menghambat proses melanogenesis. C-PC menghambat proses melanogenesis dengan dua mekanisme yakni, pertama terjadi penekanan aktivasi protein pengikat elemen cAMP response (CREB) melalui regulasi ke bawah jalur MAPK p38 dan yang kedua yakni mendegradasi faktor transkripsi terkait mikroftalmia (MITF) melalui up-regulasi jalur pensinyalan MAPK/ERK (Wu dkk., 2011). C-PC dapat memasok kelimpahan seluler adenosin monofosfat siklik (cAMP), yang mengaktifkan jalur hilir MAPK/ERK, sehingga akibatnya ada penurunan MITF. Aktivasi ERK1/2 menghasilkan fosforilasi MITF di S73, yang menginduksi degradasi proteasomal MITF. Akan tetapi, CPC juga dapat memberikan dampak negatif pada fosforilasi p38 untuk membatasi aktivasi CREB, yang dapat menghasilkan ekspresi dari gen MITF yang terbatas (Wu dkk., 2000).

\section{Aktivitas Antikollagenase dan Antielastase dari Mikroalga}

Menurut Mecham dkk. (1997), kulit manusia memiliki berbagai mekanisme perlindungan diri, salah satunya terdapat bagian bernama fibroblas yang bertanggung jawab untuk memproduksi elastin dan kolagen, yang sangat diperlukan untuk berbagai peran pelindung pada kulit manusia. Elastin memberikan elastisitas pada jaringan ikat. Namun, elastin dapat terdegradasi oleh elastase, yang merupakan enzim metalloproteinase.

Meskipun pada dasarnya elastin memiliki ketahanan yang kuat terhadap degradasi proteolitik, aktivitas paparan terus menerus dari elastase juga dapat menyebabkan kerusakan serat elastis dan menyebabkan terbentuknya kerutan. Peningkatan aktivitas elastase yang signifikan disebabkan oleh bertambahnya usia. Hal inilah yang menyebabkan terjadinya peningkatan minat masyarakat terhadap senyawa alami untuk mengurangi penuaan dan kerutan pada kulit (Onar dkk., 2012).

Extracellular matrix (ECM) mengandung kolagen yang merupakan komponen paling penting dan bertanggung 
jawab untuk fleksibilitas, elastisitas, dan ketahanan kulit. Dalam proses penuaan, kadar kolagen dan elastin menurun (terdegradasi), yang mengakibatkan hilangnya kekuatan dan kelenturan kulit, selanjutnya terbentuk kerutan (Ndlovu dkk., 2013). Degradasi kolagen dapat disebabkan oleh solar ultraviolet radiation (UVR). UVR akan menginduksi matrix metalloproteinases (MMPs) yang merupakan penyebab utama dalam degradasi kolagen dalam ECM. Tissue inhibitors of metalloproteinases (TIMPs) adalah inhibitor alami yang berfungsi untuk mengontrol ekspresi MMPs yang tidak diinginkan dan dapat melindungi ECM. Salah satu radikal bebas, reactive oxygen species (ROS) yang dihasilkan karena paparan berlebihan terhadap UVR merangsang protein kinase yang diaktifkan mitogen yang juga merangsang faktor activator protein 1 (AP-1) dan menyebabkan ekspresi MMP tidak terkontrol. Berbagai penelitian telah dilakukan untuk menemukan inhibitor alami AP-1 guna untuk menghambat ekspresi MMPs.

Bukti aktivitas anti-elastase dan anti-kolagenase dari Spirulina dan metabolitnya ditemukan pada alga laut (Thomas dkk., 2014), dan ekstrak tumbuhan (Thring dkk., 2009). Namun, secara lebih dalam masih diperlukan studi lebih lanjut mengenai mikroalga Spirulina untuk mengkonfirmasi potensi aktivitas antielastase dan antikolagenasenya.

\section{Bioplastik dari Spirulina}

Tabel 1 memperlihatkan beberapa laporan penelitian terkait potensi Spirulina platensis sebagai sumber bioplastik / Polihidroksialkanoat (PHA).

Tabel 1. Kandungan polihidroksialkanoat dari mikroalga

\begin{tabular}{lll}
\hline Mikroalga & $\begin{array}{l}\text { PHA } \\
(\% \mathrm{w} / \mathrm{w})\end{array}$ & Referensi \\
\hline Nostoc muscorum & 31 & Nishioka dkk. (2001) \\
Spirulina subsalsa & 10 & Mallick dkk. (2007) \\
Botryococcus braunii & 16,4 & Kavitha dkk. (2016) \\
Spirulina subsalsa & 7,45 & Shrivastav dkk. (2010) \\
Spirulina sp LEB-18 & 30,7 & Coelho dkk. (2015) \\
\hline
\end{tabular}

Spirulina memiliki kandungan PHA yang cenderung lebih kecil dibanding mikroalga lain seperti Nostoc muscorum yang mampu mengakumulasi PHA sampai $31 \%$. Hanya penelitian dari Coelho dkk. (2015) yang berhasil memodifikasi kondisi pertumbuhan Spirulina sp. LEB-18 sehingga diperoleh 30\% PHA. Namun demikian, kandungan komponen bioaktif dari Spirulina seperti Cphycocyanin dapat menjadikannya sebagai spesies yang dapat digunakan untuk berbagai macam aplikasi. Untuk itu diperlukan suatu konsep biorefinery dalam memproduksi bioplastik dari Spirulina agar diperoleh biaya produksi yang lebih terjangkau. Dengan menggunakan konsep biorefinery, produk turunan dari Spirulina tidak hanya berfokus pada bioplastik, tapi juga produk turunan lain yang dapat digunakan sebagai kosmetik.

\section{Konsep biorefinery}

Konsep biorefinery produksi bioplastik dan kosmetik dari Spirulina disajikan di Gambar 1.

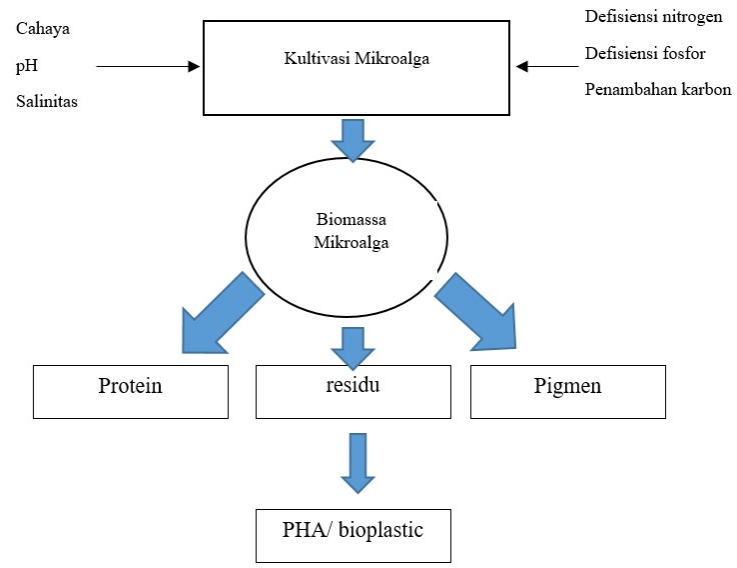

Gambar 1. Konsep biorefinery Spirulina untuk memproduksi kosmetik dan bioplastik

Spirulina memiliki kandungan protein sampai $60 \%$ dan pigmen phycocyanin sampai $15 \%$. Kedua produk ini memiliki nilai ekonomis yang tinggi. Setelah kedua produk ini diambil, residu biomassa yang masih mengandung PHA dapat diolah menjadi bioplastik.

Di samping itu, strategi lain seperti defisiensi nitrogen, penambahan asetat maupun glukosa, dapat menaikkan kadar PHA dalam biomassa seperti dalam laporan Coelho dkk. (2015). Defisiensi nitrogen dan atau fosfor cenderung menjadikan kondisi pertumbuhan Spirulina terganggu, sehingga sel Spirulina cenderung mengakumulasi atau menyimpan energi sebagai respond dari kondisi lingkungan yang kurang optimal atau tidak menguntungkan. Energi yang disimpan di dalam sel berupa PHA yang selanjutnya dapat dimanfaatkan sebagai bioplastik.

Kondisi lain yang dapat diaplikasikan adalah penambahan zat karbon organik. Penambahan zat karbon organik dapat meningkatkan kandungan bioplastik karena Spirulina memanfaatkan karbon organik sebagai sumber energi. Adanya cahaya matahari dan karbon organik secara bersamaan dapat menjadikan kelimpahan sumber energi bagi Spirulina. Spirulina menyimpan energi berlebih selama proses kultivasi ke dalam bentuk PHB. Namun demikian, defisiensi nitrogen, fosfor, dan penambahan karbon organik dapat menurunkan kandungan C-phycocyanin. Untuk itu 
diperlukan optimasi kondisi operasi selama proses kultivasi agar diperoleh nilai tertinggi dari C-phycocyanin dan bioplastik.

\section{Kesimpulan}

Mikroalga merupakan makhluk hidup bersel tunggal yang memiliki banyak aplikasi dan bernilai tinggi. Spirulina platensis merupakan spesies mikroalga / cyanobacteria yang saat ini banyak dikomersilkan karena memiliki banyak manfaat seperti kosmetik, bahan makanan, hingga bioplastik. Spirulina platensis sangat potensial digunakan sebagai komponen bioaktif pada kosmetik karena memiliki kandungan pigmen aktif C-phycocyanin yang tinggi. CPhycocyaninsecara empiris dapat menangkal melanogenesis, zat radikal bebas dan sebagai anti aging karena memiliki komponen bioaktif yang diakui sebagai bahan baku potensial untuk membuat suplemen untuk perawatan kulit. Dari konsep biorefinery, residu yang dihasilkan dari proses ekstraksi pigmen, masih dapat digunakan sebagai sumber bioplastik. Namun demikian, diperlukan optimasi kondisi operasi agar diperoleh kandungan pigmen dan bioplastik yang seimbang.

\section{Ucapan Terima Kasih}

Review paper ini didukung oleh LPPM UPN "Veteran" Yogyakarta dengan nomor kontrak B/41/UN.62/PT/IV/2021 dan didukung PT. Spiralife Bioteknologi Indonesia

\section{Daftar Pustaka}

Baroni A, Buommino E, De Gregorio V, et al, 2012, Structure and function of the epidermis related to barrier properties Clin Dermatol Vol.30, 257-262

Basavaraj KH, Seemanthini C, Rashmi R., 2010, Diet in dermatology: Present perspectives Indian J Dermatol Vol.55 No.1, 205-210.

Castro EM, Shannon E, Abu-Ghannam N., 2019, Effect of Fermentation on Enhancing the Nutraceutical Properties of Arthrospira platensis (Spirulina) Fermentation Vol. 5 No.1, 1-16.

Cadet J, Douki T, Ravanat JL, Di Mascio P., 2009, Sensitized formation of oxidatively generated damage to cellular DNA by UVA radiation Photochem Photobiol Sci Vol.8, 903-911.

Cherng SC, Cheng SN, Tarn A, Chou TC., 2007, Antiinflammatory activity of C-phycocyanin in lipopolysaccharide-stimulated RAW 264.7 macrophages Life Sci Vol.81 No.19-20, 1431-1435.
Coelho VC, da Silva CK, Terra AL, Costa JAV, de Morais MG. 2015 Polyhydroxybutyrate production by Spirulina sp. LEB 18 grown under different nutrient concentrations. African Journal of Microbiology Research, Vol. 9 No.24, 1586-1594.

Costa JAV, Barbieri Moro, GM, de Moraes Vaz Batista Filgueira D, Corsini E. Bertolin TE., 2017. The potential of Spirulina and its bioactive metabolites as ingested agents for skin care. Industrial Biotechnology Vol 13 No 5, 244-252.

Darvin ME, Jung S, Schanzer S, et al., 2015, Influence of the systemic application of blue-green Spirulina platensis algae on the cutaneous carotenoids and elastic fibers in vivo Cosmetics Vol.2, 302-312.

Farage MA, Miller KW, Elsener P, Maibach HI., 2008, Intrinsic and extrinsic factors in skin aging: A review Int J Cosmetic Sci Vol.30, 87-95.

Friedberg EC., 2016, A history of the DNA repair and mutagenesis field: the discovery of base excision repair DNA Repair Vol.37, A35-A39.

Friedman O. 2005. Changes associated with the aging face Facial Plast Surg Clin North Am Vol.13: 371-380.

Gupta NK, Gupta KP, 2012, Effects of C-phycocyanin on the representative genes of tumor development in mouse skin exposed to 12-O-tetradecanoyl-phorbol-13acetate Environ Toxicol Pharmacol Vol. 34 No. 3, 941948.

Helfrich YR, Sachs DL, Voorhees JJ., 2008, Overview of skin aging and photoaging Dermatol Nurs Vol. 20 No. 3,177-184.

Kammeyer A, Luiten RM, 2015, Oxidative events and skin aging Ageing Res Rev Vol. 21, 16-29.

Kavitha G, Kurinjimalar C, Sivakumar K, Palani P, Rengasamy R. 2016. Biosynthesis, purification and characterization of polyhydroxybutyrate from Botryococcus braunii kütz. Int J Biol Macromolecules, Vol. 89, 700-706.

Kiuru P., D’Auria M.V., Muller C.D., Tammela P., Vourela H, Yli-Kauhaluoma H, 2014, Exploring Marine Resources for Bioactive Compounds Planta Med Vol. $80,1234-1246$

Kligman LH, Kligman AM, 1986, The nature of photoaging: Its prevention and repair Photodermatol Vol. 3 No.12: 215-227.

Kohl E, Steinbauer J, Landthaler M, Szeimies RM, 2011, Skin ageing $J$ Eur Acad Dermatol Venereol Vol. 25 No. 8, 873-884.

Liu J-G, Hou C-W, Lee S-Y, et al., 2011, Antioxidant effects and UVB protective activity of Spirulina (Arthrospira platensis) products fermented with lactic acid bacteria Process Biochem Vol. 46 No. 7: 14051410 . 
Loffek S, Schilling O, Franzke C-W, 2011, Biological role of matrix metalloproteinases: A critical balance. Eur Respir J Vol. 38: 191-208.

Mallick N, Sharma L. Singh AK. 2007. Polyhydroxyalkanoate (PHA) synthesis by Spirulina subsalsa from Gujarat coast of India. Journal of Plant Physiology, 164, pp.312-317.

Milledge JJ., 2011, Commercial application of microalgae other than as biofuels: A brief review Rev. Environ. Sci. Biotechnol Vol. 10, 31-41.

Natarajan VT, Ganju P, Rammokumar A, et al, 2014, Multifaceted pathways protect human skin from UV radiation Nature Chem Biol Vol. 10, 542-551.

Naylor EC, Watson RE, Sherratt MJ, 2011, Molecular aspects of skin ageing Maturitas Vol. 69, 249-256.

Ndlovu G, Fouche G, Tselanyane M, et al, 2013, In vitro determination of the antiaging potential of four southern African medicinal plants. BMC Complem Altern Med Vol. 13, 304-310.

Nishioka M, Nakai K, Miyake M, Asada Y, Taya, M. 2001, Production of poly- $\beta$-hydroxybutyrate by thermophilic cyanobacterium, Synechococcus sp. MA19, under phosphate-limited conditions. Biotechnology letters, Vol. 23 No.14, 1095-1099.

Onar HC, Yusufoglu A, Turker G, Yanardag R., 2012, Elastase, tyrosinase and lipoxygenase inhibition and antioxidant activity of an aqueous extract from Epilobium angustifolium L. leaves $\mathrm{J}$ Med Plant Res Vol. 6, 716-726.

Osakabe A, Tachiwana H, Kagawa W, et al., 2015, Structural basis of pyrimidinepyrimidone (6-4) photoproduct recognition by UV-DDB in the nucleosome Sci Rep Vol.5.

Pandel R, Poljšak B, Godic A, Dahmane R, 2013, Skin photoaging and the role of antioxidants in its prevention ISRN Dermatol.

Peak MJ, Peak JG, Carnes BA, 1987, Induction of direct and indirect single-strand breaks in human cell DNA by farand near-ultraviolet radiations: action spectrum and mechanisms Photochem Photobiol Vol. 45 No. 3, 381387.

Poljsak B, Dahmane RG, Godic, 2012, A. Intrinsic skin aging: The role of oxidative stress Acta Dermatovenerol Alp Pannonica Adriat Vol. 21 No.2,33-6.

Quan C, Cho MK, Perry D, Quan T, 2015, Age-associated reduction of cell spreading induces mitochondrial DNA common deletion by oxidative stress in human skin dermal fibroblasts: Implication for human skin connective tissue aging J Biomed Sci Vol. 22, 62.

Romay CH, Gonzale’z R, Ledo'n N, et al, 2003, CPhycocyanin: a biliprotein with antioxidant, anti- inflammatory and neuroprotective effects Curr Protein Pept Sci Vol. 4 No.3, 207-216.

Sanchez-Ferrer A, Rodri'guez-Lo' pez JN, Garci'a-Ca'novas F, Garc1'a-Carmona F. Tyrosinase, 1995, A comprehensive review of its mechanism Biochim Biophys Acta No. 1247, 1-11.

Schafer FQ, Wang HP, Kelley EE, et al., 2002, Comparing beta-carotene, vitamin $\mathrm{E}$ and nitric oxide as membrane antioxidants. Biol Chem Vol. 383 No.(3-4), 671-681.

Singh S., Kate B.N., Banerjee, U.C., 2005, Bioactive compounds from cyanobacteria and microalgae: An overview Crit. Rev. Biotechnol, Vol. 25, 73-95.

Spolaore P., Joannis-Cassan C., Duran E., Isambert, 2006, A. Commercial applications of microalgae. J. Biosci. Bioeng. Vol. 101, 87-96.

Shrivastav A, Mishra SK, Mishra S. 2010. Polyhydroxyalkanoate (PHA) synthesis by Spirulina subsalsa from Gujarat coast of India. Int J. Biol. Macromolecules Vol. 46 No. 2, 255-260.

Taeib A, Cario-Andre M, Briganti S, Picardo M., 2011, Inhibitors and enhancers of melanogenesis. Di dalam Borovansky J, Riley PA, (ed). Melanins and Melanosomes. hlm. 117-166. Germany: WileyBlackwell.

Tamagnini, P., Axelsson, R., Lindberg, P., Oxelfelt, F., Wünschiers R., Lindblad, P, 2002, Hydrogenases and hydrogen metabolism of cyanobacteria. Microbiol. Mol. Biol. Vol. 66 ; 1-20.

Thomas NV, Manivasagan P, Kim SK., 2014, Potential matrix metalloproteinase inhibitors from edible marine algae: A review. Environ Toxicol Pharmacol Vol. 37, 1090-1100.

Thring TSA, Hili P, Naughton DP., 2009, Anti-collagenase, anti-elastase and antioxidant activities of extracts from 21 plants. BMC Compl Alt Med No. 9,1-11.

Wu LC, Lin YY, Yang SY, et al., 2011, Antimelanogenic effect of c-phycocyanin through modulation of tyrosinase expression by upregulation of ERK and downregulation of p38 MAPK signaling pathways, $J$ Biomed Sci Eng Vol.18 No.1,74.

Wu M, Hemesath TJ, Takemoto CM, et al., 2000, c-Kit triggers dual phosphorylations, which couple activation and degradation of the essential melanocyte factor $M i$ Genes Dev Vol. 14, :301-312.

Yogianti F, Kunisada M, Nakano E, et al, 2014, Inhibitory effects of dietary Spirulina platensis on UVB-induced skin inflammatory responses and carcinogenesis. $J$ Invest Dermatol Vol.134 No.10, 2610-2619.

Zouboulis CC, Makrantonaki E., 2011, Clinical aspects and molecular diagnostics of skin aging Clin Derm Vol.29 No.1,3-14. 